\title{
ASPEK PERIKLANAN MAKANAN TIDAK SESUAI DENGAN KONDISI BARANG YANG DIPERDAGANGKAN DALAM HUKUM PERLINDUNGAN KONSUMEN INDONESIA*
}

\author{
Oleh: \\ Ni Ayu Emi Sri Andari** \\ A.A. Ketut Sukranatha ${ }^{* * *}$
}

\begin{abstract}
ABSTRAK
Periklanan merupakan sebuah bagian dari penyiaran yang tidak dapat dilepaskan dalam sistem hukum modern. Pada prakteknya, penyiaran yang dilaksanakan di Indonesia cenderung dilakukan dengan tidak benar bahkan berdasarkan Penelitian Kurniawan, dari 373 iklan pangan di Indonesia, sebanyak 312 iklan atau sekitar 83,6\% iklan pangan melanggar ketentuan Kode Etik Periklanan Indonesia. Penyusunan jurnal ini diperuntukan untuk menjawab 2 (dua) rumusan masalah yakni (1) Bagaimana pengaturan periklanan makanan yang tidak sesuai dengan kenyataan? (2) Apa aspek yang mengakibatkan proses periklanan makanan di Indonesia cenderung berpotensi menyimpangi hak konsumen? Metode yang digunakan dalam penyusunan jurnal ini adalah metode penelitian hukum normatif dengan didukung pendekatan fakta, pendekatan perundang-undangan dan pendekatan analisis dan sintetis. Hasil dari penelitian ini menunjukan bahwa undang-undang perlindungan konsumen telah memberikan pengaturan terkait aspek periklanan makanan telah diatur dalam beberapa peraturan namun masih belum tegas dari sudut pandang sanksi yang dijatuhkan; sedangkan (2) kelemahan undang-undang penyiaran yang berdampak pada periklanan makanan di Indonesia terletak pada fungsi dari KPI yang masih lemah dalam legitimasinya sebagai lembaga pengawas ataupun badan legislator sehingga berdampak pada pelaksanaan fungsi dan penyimpangan terhadap peraturan yang telah ditetapkan.
\end{abstract}

Kata Kunci : Periklanan, Kode Etik, Makanan.

*Karya Ilmiah ini bukan ringkasan skripsi.

${ }^{* *}$ Ni Ayu Emi Sri Andari Nim 1516051234 adalah Mahasiswa Fakultas Hukum Universitas Udayana Program Kekhususan Hukum Bisnis.

Korespondensi dengan penulis melalui email : ayuemmy@yahoo.co.id

*** A. Ketut Sukranatha adalah dosen bagian Hukum Bisnis Fakultas Hukum Universitas Udayan. Korespondensi melalui email :

agung_sukranatha@unud.ac.id 


\begin{abstract}
Advertising is a part of broadcasting that can not be released in the modern legal system. Practically, broadcasting in Indonesia tends to be done incorrectly even on the basis of Kurniawan's Research, that show from 373 food advertisements in Indonesia, 312 advertisment or $83.6 \%$ of food advertisements violate the provisions of the Indonesian Advertising Code of Ethics. This journal is intended to answer 2 (two) formulation of the problem that is (1) How is the food advertising arrangements that do not match reality? (2) What aspects of the food advertising process in Indonesia tend to potentially distort consumer rights? The method that used in the preparation of this journal is an empirical method supported by fact approach, statue approach and analytical and synthetic approaches. The results of this study show that (1) consumer protection has provided regulation related to the advertising aspects of food has been regulated in some regulations but still not firmly from the point of view of sanctions imposed; while (2) the weakness of the broadcasting law affecting the advertising of food in Indonesia lies in the function of KPU that is still weak in its legitimacy as a supervisory body or legislator body so that it impacts on the implementation of function and deviation against established rules.
\end{abstract}

\title{
Keyboards : Advertising, Code of Conduct, Food.
}

\section{Pendahuluan}

\subsection{Latar Belakang}

Popularitas Industri periklanan di Indonesia cenderung meningkat setiap tahunnya, bahkan Laporan dari Nielsen Advertising Information Services (untuk selanjutnya disebut dengan Nielsen Indonesia) menampilkan sebuah presentasi kenaikan belanja iklan melalui Televisi dan Media Cetak yang signifikan dalam priode Januari-Juli 2017 sebesar Rp. 87.000.000.000.000.000,00 (delapan puluh tuju trilyun rupiah) dengan perincian 61,5 trilyun rupiah untuk Televisi dan 15,6 Trilyun rupiah untuk media cetak. Secara khusus kenaikan pada sektor belanja makanan sebesar 25\% dengan total dana yang didapatkan sebesar Rp. 2.500.000.000.000,00 (dua ribu lima ratus 
trilyun rupiah). ${ }^{1}$ Selebihnya didominasi oleh alat Telekomunikasi sebesar 32\% dengan kisaran pendapatan sebesar 3,7 trilyun rupiah dan layanan online sebesar $31 \%$ dengan pendapatan 3,2 trilyun rupiah. Periklanan melalui radio masih diminati oleh sebagian besar orang, sekalipun radio diidentifikasi sebagai media yang paling diminati dengan total pengguna sebesar 20,2 juta orang dengan rata-rata lama waktu penggunaan sebesar 129 menit namun indeks belanja untuk pengguna radio cenderung rendah yakni berkisar antara 811,8 milyar rupiah. ${ }^{2}$

Periklanan memegang peran yang sangat penting dan menentukan tingkat belanja sebuah produk. ${ }^{3}$ Iklan dikenal sebagai sebuah sarana komunikasi yang dilakukan dengan mempromosikan sebuah produk dan pesan kepada masyarakat luas. ${ }^{4}$ Tetapi sejalan dengan itu, proses periklanan yang ditayangkan tidak selamanya mencerminkan kenyataan yang ada. Iklan menentukan keputusan pembeli sehingga penting bagi seorang produsen untuk dapat menyajikan informasi yang menarik namun terkadang melebih-lebihkan produk yang ada sehingga banyak diminati dan berdampak pada kenaikan permintaan pasar terhadap sebuah produk. ${ }^{5}$ Padahal dalam Pasal 10 Undang-Undang Nomor 8 Tahun 1999 tentang Perlindungan Konsumen (untuk selanjutnya disebut dengan UU Perlindungan Konsumen) telah menentukan larangan terhadap seorang penjual termasuk didalamnya ialah mempromosikan sebuah produk yang

1 Nielsen, ibid.

2 Nielsem, ibid.

3 Ambar Lukitaningsih, 2013, "Iklan Yang Efektif Sebagai Strategi Komunikasi Pemasaran", Jurnal Ekonomi dan Kewirausahaan, Program Studi Ilmu Ekonomi, Fakultas Ekonomi Universitas Sarjanawiyata Tamansiswa Yogyakarta, Volume 13, Nomor 2, h. 117.

${ }^{4}$ Ambar Lukitaningsih, ibid, h. 118.

5 Priccila Natalia dan Mumuh Mulyana, 2014, "Pengaruh Periklanan Dan Promosi Penjualan Terhadap Keputusan Pembelian”, Jurnal Ilmiah Managemen, Program Studi Ilmu Manajemen, Sekolah Tinggi Ilmu Ekonomi Kesatuan Bogor, Volume 2, Nomor 2, h. 119. 
tidak sesuai dengan kondisinya. Sayangnya, persoalan demikian hingga saat ini cenderung mewarnai dunia periklanan di Indonesia.

Produk makanan yang ditawarkan oleh sejumlah produsen turut diwarnai dengan kondisi demikian, bahkan tidak lazim produk yang ditawarkan berbanding terbalik dengan kenyataan yang disajikan. Faktanya beberapa penelitian telah mengungkapkan bahwa kepuasan terhadap sebuah produk secara signifikan menentukan loyalitas dari konsumen. ${ }^{6}$ Sekalipun iklan yang ditampilkan tidak sesuai dengan kondisi yang ditawarkan namun masih banyak pihak yang menggunakan produk makanan tersebut oleh karena faktor brand (merek). ${ }^{7}$ Tingkat konsumsi sebuah brand bervariasi dan mengikuti segmen pasar yang merupakan indikator untuk mengukur tingkat peminatan sebuah produk berdasarkan kalangan usia. ${ }^{8}$ Kondisi ini perlu diantisipasi, oleh karena jika ditinggalkan berlama-lama akan memberikan sebuah dampak yang lebih besar.

Senyatanya, jika fenomena tersebut terus berlangsung maka akan secara tidak langsung menampilkan ketidakefektifan dari pelaksanaan UU Perlindungan Konsumen. Sehingga berdasarkan uraian tersebut maka penting untuk dimaknai arti penting dari pembentukan sebuah produk hukum yang notabenenya adalah untuk mengatur dan menata keadaan di masyarakat. ${ }^{9}$ Hal-hal

6 Rofi Dewantoro dan Ida Farida, (tanpa tahun), "Pengaruh Strategi Promosi, Kualitas Produk Dan Kepuasan Terhadap Loyalitas Pelanggan Tas Dan Dompet Maju Jaya Promotion Home Industry", Program Studi Ilmu Ekonomi Fakultas Ekonomi dan Bisnis Universitas Dian Nuswantoro, (tanpa volume), (tanpa tahun), h. 10.

7 Zimri Remalya Mawara, 2013, "Periklanan Dan Citra Merek Pengaruhnya Terhadap Keputusan Pembelian Kendaraan Bermotor Yamaha", Jurnal EMBA, Program Studi Ilmu Ekonomi Fakultas Ekonomi Universitas Sam Ratulangi Manado, Volume 1, Nomor 3, h. 834.

8 Zimri Remalya Mawara, ibid, h. 835.

9 Jimly Asshiddiqie, 2006, "Perihal Undang-Undang", Jakarta: Rajawali Pers, h. 1. 
tersebut yang menjadi latarbelakangi disusunya jurnal sehingga dapat memperjelas aspek penegakan hukum dalam sektor perlindungan konsumen.

\subsection{Rumusan Masalah}

1.2.1 Bagaimana pengaturan periklanan makanan yang tidak sesuai dengan kenyataan?

1.2.2 Apa aspek yang mengakibatkan proses periklanan makanan di Indonesia cenderung berpotensi menyimpangi hak konsumen? 


\subsection{Tujuan Penulisan}

1.3.1 Dapat memberikan uraian terhadap pengaturan yang ditetapkan dalam Undang-Undang Perlindungan Konsumen bagi pelaku usaha yang menyajikan produk berbeda dengan yang diiklankan dari sudut pandang intensitas, kualitas, rasa, porsi dll.

1.3.2 Dapat mendeskripsikan kelemahan dari hukum penyiaran di Indonesia ditinjau dari aspek periklanan makanan yang telah mengintegralkan kode etik periklanan terhadap potensi penyimpangan aspek perlindungan konsumen.

\section{Pembahasan}

\subsection{Metode Penelitian}

Metode yang hendak digunakan dalam penyusunan jurnal ini adalah metode penelitian hukum normatif yang menurut Dyah Ochtorina Susanti merupakan salah satu bentuk penelitian hukum (legal research). ${ }^{10}$ Metode ini didukung dengan model pendekatan fakta (the fact approach), pendekatan perundangundangan (the statue approach), dan pendekatan analisis dan sintesis (analitical and conceptual approach).11 Sumber bahan hukum primer terdiri dari bahan hukum yang mempunyai kekuatan mengikat secara umum (perundang-undangan), bahan hukum sekunder terdiri darei yang digunakan meliputi bukubuku, literatur, makalah, skripsi dan bahan-bahan hukum tertulis lainnya dan bahan hukum tresier terdiri dari berupa kamus besar bahasa indonesia dan kamus hukum. Semua bahan hukum primer maupun bahan hukum sekunder yang diterima akan

10 Dyah Octorina Susanti, 2013, "Penelitian Hukum (Legal Reseach)", Jember: Sinar Grafika, h. 1

${ }_{11}$ Mukti Fajar ND, et.al, 2013, "Dualisme Penelitian Hukum Normatif dan Empiris”, Yogyakarta: Pustaka Pelajar, h. 34. 
dikelola dengan menyertakan argumentasi yang relevan serta disajikan secara deskriptif.

\subsection{BagaimananPengaturan Periklanan Makanan Yang Tidak Sesuai Dengan Kenyataan}

Iklan atau promosi merupakan sebuah bentuk komunikasi massa yang dilakukan dengan menggunakan sarana televisi, radio maupun media cetak lainnya. ${ }^{12}$ Dalam prakteknya, periklanan tidak bergerak sendiri namun berada dibawah pengawasan Komisi Penyiaran Indonesia (untuk selanjutnya disebut dengan KPI). Apabila ditelaah, kewenangan KPI sebagaimana dimaksud dalam Pasal 8 ayat (3) huruf a Undang-Undang Nomor 32 Tahun 2002 tentang Penyiaran (untuk selanjutnya disebut UU Penyiaran) termasuk didalamnya menegaskan pelaksanaan kode etik periklanan yang mengatur tentang kelayakan informasi bagi setiap masyarakat di Indonesia. Dengan demikian, apabila terbukti sebuah lembaga penyiar maupun perseorangan sebagai pelaku usaha mempromosikan produknya dan menyimpangi aspek periklanan yang diatur dalam Pasal 46 UU Penyiaran maka pihak tersebut dapat dikenakan sanksi administratif maupun sanksi pidana.

Sehubung dengan itu, demi mempertahankan kedudukannya, KPI telah memberikan beberapa peringatan terhadap lembaga penyiaran di Indonesia sesuai dengan Memo Kebijakan KPI yang turut mempermasalahkan pelaksanaan iklan terhadap aspek perlindungan konsumen. ${ }^{13}$ Dalam penjelasannya, KPI

12 Werner J. Severin dan James W. Tankard, 2011, "Teori Komunikasi : Sejarah, Metode dan Terapan di Dalam Media Massa" (cetakan kelima), Jakarta: Prenada Media, h. 4.

13 Komisi Penyiaran Indonesia, (tanpa tahun), "Memo Kebijakan, "Upaya Peningkatan Koordinasi Pengawasan Iklan Dalam Rangka Perlindungan Konsumen”, Jakarta: KPI Indonesia, h. 1. 
menyinggung kompleksnya kode etik periklanan yang belum dilaksanakan oleh Lembaga Penyiaran Indonesia serta rendahnya partisipasi masyarakat dalam memberikan laporan menyikapi adanya pelanggaran dalam proses periklanan. ${ }^{14}$

Apabila menelaah dari Pasal 7 Undang-Undang Nomor 24 Tahun 1997 tentang Penyiaran secara eksplisit menentukan penguasaan penyiaran di Indonesia berada di tangan Pemerintah. Namun berlakunya Pasal 6 ayat (2) UU Penyiaran maka penguasaan negara atas penyiaran telah dibatasi hanya sebatas pada spektrum radio. Rumusan Pasal 5 huruf i UU Penyiaran menegaskan peruntukan penyiaran di Indonesia adalah untuk memberikan informasi yang benar dan tidak menyesatkan masyarakat. Hal ini sebelumnya juga telah ditetapkan dalam Pasal 104 ayat (1) dan (2) Undang-Undang Nomor 18 Tahun 2012 tentang Pangan yang menghendaki periklanan yang tidak menyimpangi hak konsumen untuk memperoleh informasi yang benar sesuai rumusan Pasal 4 huruf c Undang-Undang Nomor 8 Tahun 1999 tentang Perlindungan Konsumen dan kewajiban dari produsen iklan sebagai pelaku usaha dalam Pasal 7 huruf b untuk menyajikan informasi dengan benar. Etika Periklanan Indonesia (EPI) menghendaki pelaksanaan penyiaran yang jujur benar dan bertanggungjawab. ${ }^{15}$ Pembuka Kode Etik Periklanan meliputi Mukadimah, Lingkup, Asas dan Definisi menjelaskan proses periklanan harus menjunjung tinggi nilai kejujuran dan bertanggungjawab sebagai bagian dari semangat etik. ${ }^{16}$ Konsep semangat yang dimaksudkan ditetapkan sebagai kewajiban untuk

14 Komisi Penyiaran Indonesia, ibid, h. 3.

15 Dewan Periklanan Indonesia, 2007, "Etika Pariwara Indonesia: Tata Krama dan Tata Cara Periklanan”, Jakarta: Dewan Periklanan Indonesia (Indonesia Advertising Counsil), h. 18.

16 Dewan Periklanan Indonesia, ibid, h. 17-20. 
menafsirkan secara utuh dalam makna harafiah maupun jiwa EPI. ${ }^{17}$

Dian Utami Jati dalam tesisnya menyoroti bahwa proses periklanan di Indonesia sebagai poros penyiaran belum mencapai angka kematangan secara moral dan prinsipil. ${ }^{18}$ Disamping itu, Dian juga menjelaskan bahwa penyempurnaan kode etik periklanan pada tahun 2005 tidak menjadi jawaban atas pelanggaran etik yang kerap terjadi. ${ }^{19}$ Terlepas dari uraian tersebut, Dalam proses periklanan makanan di Indonesia sebagaimana diatur dalam Pasal 97 ayat (3) Undang-Undang Nomor 18 Tahun 2012 tentang Pangan telah menentukan bahwa ikan pangan yang diberikan kepada masyarakat harus mencantumkan berat bersih serta isi bersih dari sebuah pangan. Hal ini dimaksudkan untuk memberikan jaminan terhadap informasi dari pangan yang diiklankan tersebut. Kaitannnya dengan itu, Pasal 8 ayat (1) huruf b UU Perlindungan Konsumen telah turut menentukan larangan kepada penyelenggara iklan untuk tidak mencantumkan informasi yang tidak sesuai dengan apa yang diiklankan. Sebagai dampak atas tindakan yang dilakukan tersebut maka dengan mengacu pada Pasal 62 UU Perlindungan Konsumen maka denda sebesar Rp. 2.000.000.000,00 (dua milyar rupiah) menjadi sebuah tanggungan wajib bagi sang pelaku usaha.

Andri Leny Susyanty (dkk) mengutip hasil penelitian Kurniawan tahun 2008 yang menelaah 373 iklan pangan di Indonesia serta hasil akhir yang ditampilkan sebanyak 312 iklan

\footnotetext{
17 Dewan Periklanan Indonesia, ibid, h. 13.

18 Dian Utami Jati, 2013, "Pelanggaran Terhadap Kode Etik Periklanan di Indonesia, Analisis Iklan Yang Ditujukan Kepada Anak Pada Majalah Bobo Periode Tahun 2000-2010 Dilihat Dari Etik Pariwara Indonesia",Tesis, Program Studi Pasca Sarjana Ilmu Hukum Universitas Sebelas Maret Surakarta, h. XV.

19 Dian Utami Jati, ibid, h. XVI.
} 
atau sekitar 83,6\% iklan pangan melanggar ketentuan Kode Etik Periklanan Indonesia. ${ }^{20}$ Apabila dirincikan, jumlah iklan yang menyesatkan (iklan yang tidak sesuai dengan produk aslinya) mencapai 126 kasus atau sekitar 21,9\%, diikuti oleh iklan obatobatan sebanyak 117 kasus atau sekitar 20,3\% dan iklan produk olahan yang tidak benar mencapai 110 kasus atau 19,1\% diikuti oleh ketegori iklan yang tidak lengkap dll. ${ }^{21}$ Padahal, Pasal 44 ayat (1) Peraturan Pemerintah Republik Indonesia Nomor 69 Tahun 1999 tentang Label dan Iklan Pangan telah mengintegrasikan prinsip kejujuran dalam beriklan sebagai sebuah prasyarat utama periklanan di Indonesia.

Terlepas dari itu, jika mengacu pada Memo Kebijakan yang keluarkan oleh KPI, prosedur periklanan di Indonesia cenderung belum menjamin perlindungan atas konsumen oleh karena faktor keterjangkauan serta proses pengawasan iklan yang masih berjalan secara parsial dan fungsi pengawasan iklan yang masih belum terstruktur. ${ }^{22}$ Proses pengaduan dari masyarakat atas kasus instrusive advertising (iklan yang menggaggu) terhadap lembaga tertentu juga belum diungkapkan sehingg cenderung tidak dapat memberikan kepastian hukum kepada masyarakat yang mencari keadilan. Hal ini berarti bahwa pengaturan dalam Undang-Undang Nomor 18 Tahun 2012 tentang Pangan cenderung bersifat lemah substantif. Disamping itu, Pasal 1 angka 13 dan Pasal 17 ayat (2) Peraturan Pemerintah Republik Indonesia Nomor 69 Tahun 1999 tentang label dan Iklan Pangan hanya menentukan Badan Standarisasi Pangan sebagai sebuah

20 Kurniawan dalam Andi Leny Susyanty,et.al, 2013, "Kebijakan Pengawasan Iklan Pangan Olahan di Indonesia”, Jurnal Kefarmasian Indonesia, Pusat Teknologi Intervensi Kesehatan Masyarakat, Badan Litbangkes Kemenkes RI, Volume 4, Nomor 1, h. 14.

${ }^{21}$ Andi Leny Susyanty, ibid.

22 Komisi Penyiaran Indonesia, Loc.cit, h. 2. 
pelaksana tugas pemerintah yang memberikan standar kandungan terhadap sebuah produk pangan. Berbeda halnya dengan UndangUndang Nomor 32 Tahun 2002 tentang Penyiaran yang telah mengintegrasikan prinsip diversity of content (keberagaman isi) dan diversity of owneship (keberagaman kepemilikan) yang justru membedakan fungsi pengawasan berdasarkan wilayah regionalnya yakni lembaga swasta di tingkat daerah dan lembaga penyiaran publik di tingkat nasional. Pada rumusan Pasal 6 ayat (3) UU Penyiaran menentukan bahwa pelaksanaan penyiaran dilaksanakan pada stasiun lokal maupun stasiun nasional dengan tetap menjadi bagian dari sistem penyiaran nasional yang berada dibawah pengawasan KPI.

Disamping itu, jika mengacu pada Pasal 31 Undang-Undang Nomor 8 Tahun 1999 tentang Perlindungan Konsumen, perlindungan terhadap aspek periklanan pangan di tingkat nasional dipegang oleh Badan Perlindungan Konsumen Nasional (untuk selanjutnya disingkat BPKN) yang menjalankan tugas sebatas menerima laporan dari masyarakat sesuai rumusan Pasal 34 ayat (1) huruf f. Disamping itu, BPKN juga memiliki kewenangan untuk mendorong terlaksananya fungsi Lembaga Perlindungan Konsumen Swadaya Masyarakat dalam rumusan Pasal 34 ayat (1) huruf d Undang-Undang Nomor 8 Tahun 1999 tentang Perlindungan Konsumen. Pada tingkat daerah, fungsi perlindungan konsumen dijalankan oleh Lembaga Perlindungan Konsumen Swadaya Masyarakat yang memiliki tugas untuk memperjuangkan hak masyarakat sebagai konsumen jika mengacu pada Pasal 44 ayat (3) Undang-Undang Nomor 8 Tahun 1999 tentang Perlindungan Konsumen.

Dengan demikian, maka dapat disimpulkan bahwa pengaturan terhadap pelaksanaan penyiaran di Indonesia telah 
jelas jika melihat dari aspek perlindungan dan pengawasan yang ditentukan dalam peraturan perundang-undangan namun yang masih menjadi permasalahan ialah pelaksanaan dari ketentuan tersebut, termasuk didalamnya kewenangan untuk menjatuhkan sanksi dan badan yang berwenang dalam menjatuhkan sanksi cenderung belum tegas ditetapkan dalam Undang-Undang. Hal ini yang melatarbelakangi tingginya pelanggaran terhadap aspek periklanan makanan yang berkenaan dengan perlindungan konsumen di Indonesia.

\subsection{Apa Aspek yang Mengakibatkan Proses Periklanan Makanan di Indonesia Cenderung Berpotensi Menyimpangi Hak Konsumen}

Menarik untuk dicermati bahwa aspek yang melatarbelakangi peningkatan periklanan makanan yang tidak sesuai dengan kenyataannya terletak pada aturannya sendiri. Jika meninjau dari Pasal 104 ayat (1) Undang-Undang Nomor 18 Tahun 2012 tentang Pangan, telah ditentukan bahwa segala bentuk iklan berkenaan dengan pangan dilarang untuk memuat informasi ataupun penawaran yang menyesatkan. Dalam konteks ini, maksud dari menyesatkan adalah memberikan informasi yang tidak sesuai dengan produk yang ditawarkan. Persoalan demikian telah diatur dalam Pasal 4 huruf c UU Perlindungan Konsumen yang menekankan hak konsumen untuk mendapatkan informasi dengan benar. Pasal 4 huruf $h$ turut menegaskan kompensasi atas kerugian konsumen yang tidak mendapatkan sesuatu sebagaimana mestinya. Lebih lanjut dalam Pasal 104 ayat (3) ditegaskan bahwa dalam hal terjadi iklan yang menyesatkan maka kewenangan atas penindakan persoalan tersebut berada di bawah tangan Pemerintah. Hal yang menarik untuk diamati disini ialah ketika sebuah perusahaan-perusahaan waralaba (franchising) dan 
perusahaan lainnya harus bersaing untuk menawarkan sebuah produk tanpa harus merugi. ${ }^{23}$ Willy menjelaskan bahwa terdapat 4 unsur penting dalam proses periklanan yakni product, price, place dan promotion. ${ }^{24}$ Masing-masing tahap tersebut memiliki peran yang sangat penting.

Terlepas dari pembahasan tersebut, penting untuk disoroti bahwa persoalan mendasar disini terletak pada proses penyiaran di Indonesia belum mendapatkan pengawasan yang maksimal oleh karena lemahnya aturan hukum yang mengatur, alhasil produk yang diiklankan cenderung berbanding terbalik dengan kenyataan. Memo Kebijakan telah menekankan bahwa rendahnya partisipasi masyarakat dalam memberikan laporan terhadap iklan yang ditayangkan turut menjadi persoalan yang harus diselesaikan. ${ }^{25}$ Data yang ditampilkan oleh Badan Ekonomi Kreatif menampilkan bahwa dalam presentasi 100\%, kuliner makanan memegang posisi peminatan tertinggi yakni mencapai 41,69\% diikuti oleh fashion mencapai $18,15 \%$ dan kriya $15,70 \%$ dan alat-alat lainnya. ${ }^{26}$ Potensi ini kemudian dimanfaatkan sebagai sarana publikasi citra merek dari sebuah produk oleh perusahaan demi mendapatkan provit. ${ }^{27}$ Kewenangan pengawasan pemerintah terhadap penyiaran dilakukan oleh KPI sebagaimana ditetapkan pada Pasal 7 dan Pasal 8 UU Penyiaran. Sekalipun demikian, KPI masih ditentang dalam menjalankan fungsi pengawasan. Redi Panuju mengungkapkan bahwa KPI hanya sekedar menjalankan fungsi

23 Willy Al Baihaqie, 2010, "Pengaruh Periklanan Terhadap Minat Beli Konsumen Starbucks Coffee Di Bandung Indah Plaza”, Skripsi, Program Studi Ilmu Ekonomi Jurusan Manajemen S1 Fakultas Bisnis dan Manajemen Universitas Widyatama, h. 1.

24 Willy Al Bahaqie, ibid.

${ }^{25}$ Komisi Penyiaran Indonesia, ibid, h. 4.

26 Direktorat Riset dan Pengembangan Ekonomi Kreatif Badan Ekonomi Kreatif, 2017, "Data Statistik dan Hasil Survei Ekonomi Kreatif Kerjasama Badan Ekonomi Kreatif Dan Badan Pusat Statistik", Jakarta: Badan Pusat Statistik, h. 4

${ }^{27}$ Zimri Remalya Mawara, ibid, h. 829. 
pengawasan. ${ }^{28}$ Sedangkan Denico Doly berpendapat bahwa fungsi dari KPI adalah sebagai badan regulator yang memegang peran utama dalam sistem penyiaran di Indonesia. ${ }^{29}$

Lemahnya substansi yang mengatur terkait kewenangan KPI menjadi kendala utama dalam konsep penyiaran di Indonesia. Dalam hal perlindungan konsumen, Pasal 29 ayat (3) UU Perlindungan Konsumen telah mengatur secara eksklusif bahwa Menteri yang berwenang menyelenggarakan perlindungan konsumen. Menyikapi persoalan ini, maka dapat diindikasikan bahwa KPI dibenarkan sebagai lembaga pengawas bukan badan regulator. Pemegang fungsi regulator hanya diletakan pada Menteri Telekomunikasi dan Informasi. Judhariksawan berpendapat bahwa aspek hukum perijinan penyiaran merupakan sebuah konsep yang tidak dapat dilepaskan dari sistem penyiaran. ${ }^{30}$ Menyikapi persoalan demikian, maka Pemerintah harus mampu untuk memperkuat kedudukan dari KPI sebagai praktek hukum yang responsif. ${ }^{31}$ Dalam rubrik yurisprudensi, Mahkamah Konsituti telah menetapkan Putusan Nomor 005/PUUI/2003 yang membatasi kesempatan KPI untuk merumuskan peraturan di bidang penyiaran bersama dengan pemerintah. Semangat pembentukan Etika Pariwara Indonesia sebagaimana diungkapkan dalam Mukadimah menjelaskan bahwa komitmen dihadirkannya etika dalam pranata penyiaran nasional ditujukan

${ }^{28}$ Redi Panuju, 2017, "Pengawasan Iklan Pelayanan Kesehatan Tradisional di Televisi”, Jurnal Studi Komunikasi, Program Studi Ilmu Komunikasi Fakultas Komunikasi Universitas dr. Soetomo Indonesia, Volume 1, Nomor 2, h. 200.

29 Denico Doly, 2013, "Urgensi Perubahan Undang-Undang Nomor 32 Tahun 2002 Tentang Penyiaran", Jurnal Negara Hukum, Bidang Hukum Pusat Pengkajian, Pengolahan Data dan Informasi Setjen DPR RI, Volume 4, Nomor 2, h. 221.

30 Judhariksawan, 2010, "Hukum Penyiaran", Jakarta: Rajagrafindo Persada, h. 6.

31 Mohhamad Mahfud, 2010, "Politik Hukum di Indonesia", Jakarta: Raja Grafindo Persada Press, h. 25.; 
untuk menjaga khalayak penayangan iklan dalam sebuah tatanan yang kompleks. Pernyataan yang menghadirkan etika tersebut penting untuk dimaknai sebagai sebuah komitmen sehingga pelaksanaan periklanan di Indonesia tidak menyimpangi hak dari konsumen yang telah dijamin oleh hukum.

Hadirnya Putusan Mahkamah Konstitusi Nomor 005/PUUI/2003 pada tanggal 6 Agustus 2004 menggagas paradigma baru dalam sistem penyiaran nasional. Sekalipun di satu Mahkamah menjelaskan bahwa KPI sebagai lembaga yang independen seharusnya diberikan kewenangan regulasi di bidang penyiaran. Namun di lain pihak, Mahkamah juga berpandangan bahwa Presiden merupakan pimpinan eksekutif tertinggi dapat saja membuat peraturannya dengan berkoordinasi dengan lembaga terkait tetapi tidak seharusnya dirumuskan dalam peraturan. Hadirnya peran serta KPI bersama Presiden dalam menentukan peraturan di bidang penyiaran dinilai dapat menyimpangi sistem ketatanegaraan yang ada. Keterlibatan dari KPI tersebut harus dimaknai sebagai lembaga negara yang menjalankan fungsi pemerintahan sebagaimana diatur dalam Peraturan Pemerintah bukan justru terlibat aktif dalam proses perumusan peraturan tersebut. Diakhir dari argumentasinya, Mahkamah berpandangan bahwa fungsi Yustisi, eksekutif dan legislatif harus sepenuhnya dikembalikan kepada Presiden.

Kondisi demikian berdampak pada melemahnya fungsi dari KPI sebagai badan pengawas penyiaran di Indonesia, bahkan sebagaimana diungkapkan bahwa sejak hadirnya putusan tersebut, KPI dipandang sebagai lembaga negara yang hanya berwenang memberikan pengawasan bukan peringatan yang tegas. Redi Panuju berpendapat bahwa KPI dapat memberikan pengawasan terhadap iklan ataupun tayangan yang menyimpangi 
kode etik namun dalam jangka waktu 7 (tujuh) hari saja, selebihnya program tersebut dapat kembali tayang dengan judul yang berbeda. ${ }^{32}$ Hal tersebut diilustrasikan dengan adanya acara "Empat Mata" yang dihentikan namun tetap kembali ditayangkan dengan nama program yang berbeda yakni "Bukan Empat Mata". 33

\section{Penutup}

\subsection{Kesimpulan}

Berdasarkan hasil analisis yang telah dipaparkan diatas, diperoleh kesimpulan sebagai berikut :

(1) Pengaturan terhadap makanan yang diiklankan di Indonesia secara implisit telah diatur dalam Undangundang perlindungan konsumen. Secara tegas dalam Pasal 46 UU Penyiaran telah ditetapkan bahwa promosi palsu dapat berujung pada pengenaan sanksi administratif yakni pencabutan izin siaran bahkan pengenaan sanksi pidana dengan denda. Berkenaan dengan itu, Pasal 62 UU Perlindungan Konsumen memungkinkan seorang pelaku usaha membayar sebesar Rp. 2.000.000.000,00 untuk kesalahan yang dilakukan. Namun masih terdapat kelemahan pada setiap peraturan tersebut yakni lemahnya fungsi yang dijalankan oleh setiap lembaga yang diatur dalam produk hukum tersebut dalam menjalankan kewenangan pengawasan.

(2) Aspek yang mengakibatkan lemahnya undang-undang penyiaran di Indonesia terletak pada aktualisasi aturan

32 Redi Panuju, Loc.cit, h. 221.

33 Redi Panuju, ibid. 
hukum tersebut. Jika meninjau dari kewenangan, maka KPI merupakan sebuah badan pengawasan terhadap jalannya penyiaran di Indonesia. KPI terbilang bukan sebagai lembaga regulator atau lembaga yang berwenang menetapkan peraturan hukum padahal statusnya sebagai komisi yang bersifat Independen dan memiliki fungsi untuk mengurus permasalahan pada sektor penyiaran. Kedudukan KPI masih berada dibawah Kementrian Komunikasi dan Informatika Republik Indonesia bahkan cenderung menjalankan arahan dari Kementrian Komunikasi dan Informatika Republik Indonesia sehingga politik hukum dibentuknya KPI tersebut tidak dapat berjalan sesuai dengan semangat pariwara yang dicitakan.

\subsection{Saran}

Berdasarkan hasil analisis yang telah dipaparkan diatas, diperoleh saran sebagai berikut :

(1) Sekalipun telah diatur namun UU Perlindungan Konsumen patut untuk dipertegas kembali dengan memperkuat legitimasi dari lembaga perlindungan konsumen yang bergerak pada sektor penyiaran Indonesia.

(2) Proses periklanan makanan harus sesuai dengan kenyataan produk yang diiklankan. Produsen makanan wajib memberikan informasi yang benar, jelas, dan jujur mengenai kondisi dan jaminan barang dan/atau jasa yang akan diiklankan. Periklanan melalui media penyiaran harus memiliki aturan hukum yang lebih jelas dan mengikat. 


\section{DAFTAR PUSTAKA}

\section{Buku}

Asshiddiqie, Jimly. 2006. "Perihal Undang-Undang”. Jakarta: Rajawali Pers.

Dewan Periklanan Indonesia. 2007. "Etika Pariwara Indonesia: Tata Krama dan Tata Cara Periklanan”. Jakarta: Dewan Periklanan Indonesia (Indonesia Advertising Counsil).

Direktorat Riset dan Pengembangan Ekonomi Kreatif Badan Ekonomi Kreatif. 2017. "Data Statistik dan Hasil Survei Ekonomi Kreatif Kerjasama Badan Ekonomi Kreatif Dan Badan Pusat Statistik”. Jakarta: Badan Pusat Statistik.

Komisi Penyiaran Indonesia. (tanpa tahun). "Memo Kebijakan, Upaya Peningkatan Koordinasi Pengawasan Iklan Dalam Rangka Perlindungan Konsumen”. Jakarta: KPI Indonesia.

Judhariksawan. 2010. “Hukum Penyiaran”. Jakarta: Rajagrafindo Persada.

Mahfud, Mohhamad. 2010. "Politik Hukum di Indonesia”. Jakarta: Raja Grafindo Persada Press.

Marzuki, Peter Mahmud. 2005. "Penelitian Hukum". Jakarta: Prenada Media.

ND, Mukti Fajar. et.al. 2013. "Dualisme Penelitian Hukum Normatif dan Empiris”. Yogyakarta: Pustaka Pelajar.

Severin, Werner J. dan James W. Tankard. 2011. "Teori Komunikasi : Sejarah, Metode dan Terapan di Dalam Media Massa". (cetakan kelima). Jakarta: Prenada Media.

Susanti, Dyah Octorina. 2013. "Penelitian Hukum (Legal Reseach)". Jember: Sinar Grafika.

\section{Jurnal Ilmiah}

Dewantoro, Rofi dan Ida Farida, (tanpa tahun). "Pengaruh Strategi Promosi, Kualitas Produk Dan Kepuasan Terhadap Loyalitas Pelanggan Tas Dan Dompet Maju Jaya Promotion Home Industry". Program Studi Ilmu Ekonomi Fakultas Ekonomi 
dan Bisnis Universitas Dian Nuswantoro. (tanpa volume). (tanpa tahun).

Doly, Denico. 2013. "Urgensi Perubahan Undang-Undang Nomor 32 Tahun 2002 Tentang Penyiaran”. Jurnal Negara Hukum. Bidang Hukum Pusat Pengkajian. Pengolahan Data dan Informasi Setjen DPR RI. Volume 4. Nomor 2.

Lukitaningsih, Ambar. 2013. "Iklan Yang Efektif Sebagai Strategi Komunikasi Pemasaran". Jurnal Ekonomi dan Kewirausahaan. Program Studi Ilmu Ekonomi. Fakultas Ekonomi Universitas Sarjanawiyata Tamansiswa Yogyakarta. Volume 13. Nomor 2.

Mawara, Zimri Remalya. 2013. "Periklanan Dan Citra Merek Pengaruhnya Terhadap Keputusan Pembelian Kendaraan Bermotor Yamaha”. Jurnal EMBA. Program Studi Ilmu Ekonomi Fakultas Ekonomi Universitas Sam Ratulangi Manado. Volume 1. Nomor 3.

Natalia, Priccila. dan Mumuh Mulyana. 2014. "Pengaruh Periklanan Dan Promosi Penjualan Terhadap Keputusan Pembelian”. Jurnal Ilmiah Managemen. Program Studi Ilmu Manajemen, Sekolah Tinggi Ilmu Ekonomi Kesatuan Bogor. Volume 2. Nomor 2.

Panuju, Redi. 2017. "Pengawasan Iklan Pelayanan Kesehatan Tradisional di Televisi”. Jurnal Studi Komunikasi. Program Studi Ilmu Komunikasi Fakultas Komunikasi Universitas dr. Soetomo Indonesia. Volume 1. Nomor 2.

Susyanty,Andi Leny. et.al. 2013. "Kebijakan Pengawasan Iklan Pangan Olahan di Indonesia”. Jurnal Kefarmasian Indonesia. Pusat Teknologi Intervensi Kesehatan Masyarakat. Badan Litbangkes Kemenkes RI, Volume 4. Nomor 1.

\section{Peraturan Perundang-Undangan}

Undang-Undang Dasar Tahun 1945

Undang-Undang Nomor 8 Tahun 1999 tentang Perlindungan Konsumen, Diundangkan di Jakarta pada tanggal 20 April 1999 dalam Lembar Negara Republik Indonesia Tahun 1999 
Nomor 42 dan Tambahan Lembar Negara Republik Indonesia Nomor 3821.

Undang-Undang Nomor 32 Tahun 2002 tentang Penyiaran Diundangkan di Jakarta pada tanggal 28 Desember 2002 dalam Lembar Negara Republik Indonesia Tahun 2002 Nomor 139 dan Tambahan Lembar Negara Republik Indonesia Nomor 4252.

Undang-Undang Nomor 18 Tahun 2012 tentang Pangan Diundangkan di Jakarta pada tanggal 16 November 2012 dalam Lembar Negara Republik Indonesia Tahun 2012 Nomor 227 dan Tambahan Lembar Negara Republik Indonesia Nomor 5360 .

Peraturan Pemerintah Republik Indonesia Nomor 69 Tahun 1999 tentang Label dan Iklan Pangan, Diundangkan di Jakarta pada tanggal 21 Juli 1999 dalam Lembar Negara Republik Indonesia Tahun 1999 Nomor 131 dan Tambahan Lembar Negara Republik Indonesia Nomor 3867.

Peraturan Pemerintah Republik Indonesia Nomor 57 Tahun 2001 Tentang Badan Perlindungan Konsumen Nasional, diundangkan di Jakarta, pada tanggal 21 Juli 2001 dalam Lembar Negara Republik Indonesia Tahun 2001 Nomor 102 dan Tambahan Lembar Negara Republik Indonesia Nomor 4125

Peraturan Pemerintah Republik Indonesia Nomor 58 Tahun 2001 Tentang Pembinaan Dan Pengawasan Penyelenggaraan Perlindungan Konsumen, diundangkan di Jakarta, pada tanggal 21 Juli 2001 dalam Lembar Negara Republik Indonesia Tahun 2001 Nomor 103 dan Tambahan Lembar Negara Republik Indonesia Nomor 4126.

Putusan Mahkamah Konstitusi Nomor 005/PUU-I/2003, diterbitkan pada Jumat, tanggal 06 Agustus 2004 dalam Berita Negara Republik Indonesia Nomor 63 Tahun 2004.

Kode Etik Pariwara Indonesia hasil amandemen 2014, diterbitkan oleh Dewan Periklanan Indonesia (Indonesian Advertising Counsil).

\section{Skripsi}


Baihaqie, Willy Al. 2010. "Pengaruh Periklanan Terhadap Minat Beli Konsumen Starbucks Coffee Di Bandung Indah Plaza".

Skripsi. Program Studi Ilmu Ekonomi Jurusan Manajemen

S1 Fakultas Bisnis dan Manajemen Universitas Widyatama.

\section{Tesis}

Jati, Dian Utami. 2013. "Pelanggaran Terhadap Kode Etik Periklanan di Indonesia, Analisis Iklan Yang Ditujukan Kepada Anak Pada Majalah Bobo Periode Tahun 2000-2010 Dilihat Dari Etik Pariwara Indonesia". Tesis. Program Studi Pasca Sarjana Ilmu Hukum Universitas Sebelas Maret Surakarta.

\section{Internet}

Nielsen. 2017. "Belanja Iklan Tumbuh Perlahan", diakses dari http://ww w.nielsen.com/id/en/press-room/2017/belanjaiklan-tumbuh-perl ahan.html, pada tanggal 19 Juni 2018 Pukul 15.34 WITA. 